\title{
COVID-19 “Evde Kal” Sürecinin Anne Görüşlerine Göre Okul Öncesi Dönem Çocuklarının Günlük Yaşamlarına Yansıması
}

\author{
CEREN ARI ARAT \\ HÜLYA GÜLAY OGELMAN
}

Özet

Bu araştırmada COVID-19 “evde kal” sürecinin anne görüşlerine göre çocukların günlük yaşamlarına yansımalarının incelenmesi amaçlanmıştır. Araştırmanın çalışma grubu Bayburt ilinde okul öncesi eğitim alan ve normal gelişim özelliği gösteren 5 yaş grubundan 137 ( $n=70 \mathrm{kız}, \mathrm{n}=67$ erkek) çocuk ve annelerinden oluşmaktadır. Araştırmada araştırmacılar tarafından geliştirilen Çevrimiçi Anket Formu kullanılmıştır. Araştırma tarama modeli ile gerçekleştirilmiştir. Elde edilen veriler betimsel analiz yöntemi ile çözümlenmiştir. Araştırmanın bulgularında; çocukların \%86,9'unun COVID-19 ile ilgili sorular sorduğu ve annelerin \%37,8'inin çocukların sorduğu soruları yanıtlarken kendini yeterli hissettiği, çocukların \%61,3'ünün uyku düzeninin bozulduğu ve \%40,1'inin beslenme düzeninin bozulduğu belirlenmiştir. Çocukların sokağa çıkma yasağına üzülme, bunalma, sıkılma, korkma ve kızma gibi olumsuz tepkiler, anlayışla karşılama ve uyum sağlama gibi olumlu tepkiler verdiği ve bu tepkilerin yanı sıra değişken tepkiler verdiği veya bazılarının herhangi bir tepki vermediği ortaya koyulmuştur. Annelerin 119'unun çocuklarına kitap, oyuncak ve materyaller

- ARASTIRMA MAKALESI-

CEREN ARI ARAT, cerenariarat@bayburt.edu.tr Bayburt Üniversitesi

ORCiD: https://orcid.org/0000-0002-5795-8901

Cocuk ve Medeniyet
HÜLYA GÜLAY OGELMAN, hülya.gulay@gmail.com

Sinop Üniversitesi

ORCiD: https://orcid.org/0000-0002-4245-0208

Geliș Tarihi: 31.03.2021 • Kabul Tarihi: 10.10.2021

doi: https://doi.org/10.47646/CMD.2021.233 
aldığı, 119 annenin aldığı 204 çeşit kitap, oyuncak ve materyal içinden 95'inin kitap olduğu ve bu kitapların 48'inin hikaye kitabı olduğu analiz edilmiştir. COVID-19 salgınını çocukların \%73'ü anne-babalarından öğrenmiştir. Annelerin \%72,3'ü COVID-19 salgınında uzaktan eğitimi yeterli bulmamışlardır. Annelerin \%73'üi uzaktan eğitimde çeşitli konularda (alt yapı yetersizliği, çocuğun dikkatini toplama, etkinlik yaptırma vs.) zorluklar yaşamışlardır. Annelerin \%92'si çocukların hareket etme ihtiyacını çeşitli yollarla gidermeye çalışmışlardır.

Anahtar kelimeler: COVID-19, küçük çocuklar, sosyal izolasyon, okul öncesi, günlük rutin

\begin{abstract}
This study aims to examine the reflections of the COVID-19 "stay at home" period on the daily lives of children according to the mothers' views. The study group consists of 137 children ( $n=70$ girls, $n=67$ boys) selected among the 5 -year-old children attending preschool education in Bayburt and indicating normal development characteristics along with their mothers. An Online Survey Form developed by the researchers was used in the study. The study was carried out with a scanning model. The data obtained were analyzed by descriptive analysis method. Among the findings of the study, it was determined that $86.9 \%$ of the children asked questions about COVID-19 and $37.8 \%$ of the mothers felt sufficient in answering the questions asked by the children. In addition, it was determined that $61.3 \%$ of the children had a disrupted sleep pattern and $40.1 \%$ had a disrupted diet during this period. It was determined that children gave negative reactions to the curfew such as feeling sad, depressed, bored, afraid and angry along with positive reactions such as comprehending and adapting. Besides these reactions, some children reacted variously while some did not even react. It was analyzed that 119 of the mothers bought books, toys and materials for their children during this period. Of 204 kinds of materials bought by those 119 mothers, 95 were books of which 48 were storybooks. $73 \%$ of children learned about the COVID-19 pandemic from their parents. $72.3 \%$ of the mothers did not find distance learning sufficient during the COVID-19 pandemic. $73.0 \%$ of the mothers had difficulties in various issues (lack of infrastructure, concentration of children, doing activities etc.) related to distance learning. $92.0 \%$ of the mothers tried to find alternative ways to meet the need for movement of their children.
\end{abstract}

Keywords: COVID-19, young children, social isolation, preschool, daily routine

32

Çocuk ve Medeniyet 2021/1

\section{Giriş}

İnsanlarda genellikle soğuk algınlığı seviyesinde belirtiler gösteren ve RNA virüs ailesinden olduğu bilinen koronavirüsler $(\mathrm{CoV})$ aynı aileden olan SARS-CoV ve MERS-CoV ile daha ciddi hastalıklara sebebiyet 
verebildiğini göstermiştir. Yüzeyinde yer alan çubuksu uzantılarının taç şekline benzemesinden dolayı, Latince karşılığı taç olan corona kelimesiyle birlikte bu virüs Dünya Sağlık Örgütü (WHO) tarafından koronavirüs olarak adlandırılmıştır (WHO, 2020b; T.C. Sağlık Bakanlığı, 2020).

Yeni Koronavirüs (COVID-19), 2019 yılının son aylarında ilk olarak Çin'de görülmeye başlanmıştır. Başlangıçta vakaların \%80'i Çin'de görülürken 2020 Mart ayı itibari ile yaklaşık 3 ay gibi bir sürede dünya genelinde küresel bir salgın halini almaya başlamıştır (Jiao vd., 2020). COVID-19, bu hızlı yayılımı sebebiyle Dünya Sağlık Örgütü (DSÖ) tarafından salgın olarak ilan edilmiştir. DSÖ’nün 23 Ağustos 2021 verilerine göre Covid-19'dan kaynaklı doğrulanmış 213 milyondan fazla vaka tespit edilmişken 4 buçuk milyon kişi Covid-19 salgınına bağlı olarak hayatını kaybetmiştir (WHO, 2021).

Tüm dünyaya yayılım sağlayan COVID-19 halk sağlığı üzerinde ciddi etkiler göstermiştir. COVID-19 ortaya çıktıktan sonra virüsü kontrol altına almak için çeşitli tedbirler de alınmaya başlanmıştır. Alınan bu tedbirlerin uzun vadede çocuklar ve aileler üzerinde istenmeyen etkilerinin olabileceği öngörülmektedir. Örneğin, COVID-19'un yayılmasını yavaşlatmak için birçok ülkede okullar uzaktan eğitime geçmiş ve 2021 yılının son çeyreğine gelinen günümüzde hala uzaktan eğitim devam etmektedir. Birleşmiş Milletler Eğitim, Bilim ve Kültür Örgütü'ne (UNESCO, 2020a) göre, okul öncesi, ilkokul ve ortaokul seviyelerinde çocukların okula gittiği 106 ülkede 1,05 milyardan fazla öğrenci (toplam kayıtlı öğrencilerin\% 60,5’i) okulların kapanmasından etkilenmiştir. Buna karşılık, eğitimciler müfredatlarını öğrencilerin uzaktan eğitime katılabilecekleri şekilde uyarlamışlardır. Okulların uzaktan eğitim sunmaya hazır olma durumları, okul ve ailenin çocuğa sunabilecekleri kaynaklara bağlı olarak bazı eşitsizlikleri de beraberinde getirecektir (Tran vd, 2020). Küçük çocukların evde öğrenmeleri, ebeveyn desteği ihtiyacı olduğunu da göstermektedir. Uzaktan öğrenmeye bu ani geçiş ve bunun getirdiği zorluklar bir yandan da endişe vericidir. Çünkü ebeveynlere uygun destek sağlanmadan, ani bir şekilde meydana gelen bu değişiklikler ebeveynlerin, ebeveynlik stresi ve ebeveyn tükenmişliği yaşama olasılığını artırabilir ve bu da çocukları olumsuz yönde etkileyebilir (Griffith, 2020).

COVID-19 ile ilişkili olarak kamusal alanda meydana gelen risk faktörlerini en aza indirmek, yeterli sağlık hizmeti sunabilmek kısacası salgının etkilerini en aza indirgemek amacıyla sinema salonlarının, müzelerin, tiyatroların geçici olarak kapatılması gibi birçok tedbir alınmıştır. Bu tedbirlerin eğitimi ilgilendiren kısmı ise 16 Mart 2020 tarihi itibariyle yüz yüze eğitime ara verilmesidir. Aranın ardından 23 Mart 2020 tarihi itibariyle 
eğitim kurumları uzaktan eğitime geçmiştir. 3 Nisan 2020 tarihi itibariyle de en fazla 20 yaş altı ve 65 yaş altını kapsayan tedbirler içeren sokağa çıkma yasakları uygulanmaya başlanmıştır (Türkiye Cumhuriyeti İçişleri Bakanlığı, 2020). Sokağa çıkma yasağı önce belirli illerde, belirli yaş gruplarında ve belirli günlerde uygulanmış, daha sonra yasak ülke genelini kapsamıştır. Bu yasak en fazla çocukları ve 65 yaş üstü yaşlıları etkilemiş, onların evde kalma sürelerini ve günlük yaşam rutinlerini değiştirmiştir.

COVID-19 salgınında 65 yaş ve üstü bireyler en savunmasız ve etkiye en çok açı grup olduklarından dolayı kısıtlamalara maruz kalırken 20 ve daha küçük yaş grubu ise özellikle taşıyıcı olarak ifade edilmelerinden kaynaklı sosyal izolasyon için önemli gruplar olarak belirlenmişlerdir (Üstün ve Özçiftçi, 2020). Almanya, Birleşik Krallık ve Amerika'yı kapsayan bir çalışmada bireylerin genel yaşam tarzlarında meydana gelen değişiklikler ortaya koyulmuştur (Kunst, 2020).

Tablo 1. COVID-19 salgını sürecinde Almanya, Birleşik Krallık ve Amerika'da genel yaşam tarzında meydana gelen değişiklikler

\begin{tabular}{|l|l|l|l|}
\hline & $\begin{array}{l}\text { Almanya } \\
(\%)\end{array}$ & $\begin{array}{l}\text { Birleşik } \\
\text { Krallı (\%) }\end{array}$ & $\begin{array}{l}\text { Amerika } \\
(\%)\end{array}$ \\
\hline Evde kalma süresindeki artış & 71 & 84 & 77 \\
\hline Ellerin daha fazla yıkanması & 70 & 75 & 73 \\
\hline Sosyal mesafeye uyulması & 61 & 78 & 69 \\
\hline Dışarıda koruyucu yüz maskesi kullanma & 52 & 20 & 66 \\
\hline Bar ve restoran gibi alanlardan kaçınma & 58 & 67 & 65 \\
\hline Alışverişe gitmeyi azaltma & 59 & 71 & 62 \\
\hline Seyahat etmeyi azaltma & 51 & 69 & 56 \\
\hline $\begin{array}{l}\text { Arkadaşlar ya da aile ile yapılan planları iptal } \\
\text { etme }\end{array}$ & 54 & 62 & 53 \\
\hline Online alışverişi artırma & 30 & 46 & 52 \\
\hline Evi daha fazla temizleme & 20 & 40 & 43 \\
\hline Ödemelerde nakit para kullanımını azaltma & 35 & 63 & 36 \\
\hline $\begin{array}{l}\text { Belirli saatlerde (yoğun) alışveriş yapmamaya } \\
\text { Özen gösterme }\end{array}$ & 50 & 60 & 36 \\
\hline Yaşam tarzında değişiklik yapmama & 37 & 43 & 35 \\
\hline Egzersiz yapmada azalma & 20 & 19 & 16 \\
\hline
\end{tabular}

Kaynak: Kunst, 2020 
COVID-19 salgını sürecinde sokağa çıkma yasakları sırasında bireylerin düşük seviyede fiziksel aktivite gerçekleştirdiği ve buna bağlı olarak yaşam kalitesi, genel sağlık algısı ve ağrı düzeylerinin etkilendiği belirlenmiştir (Tural, 2020). COVID-19 salgını sürecinde egzersiz yapan bireylerde yaşam kalitesinin egzersiz yapmayanlardan daha yüksek olduğu tespit edilmiştir (Çağlayan-Tunç vd., 2020). Maske kullanımı, sosyal mesafeye uyulması ve hijyen konularında dikkatli olunması gibi önlem unsurlarının işleyişi sosyal yaşamda bireylerin yaşam tatminlerini artırmaktadır (Bilgin ve Diğer, 2021).

Küresel olarak COVID-19 salgını bireylerin sağlığını önemli ölçüde etkilemiştir. Bu salgın yeni bir normale uyum sağlama ve günlük yaşamda yeni rutinler oluşturma gerekliliğini de beraberinde getirmiştir (WFOT, 2020). Okula giden, sokağa çıkan, akranları ya da tanıdıkları ile bir araya gelen çocukların günlük yaşamlarında da önemli değişiklikler olmuştur. Alanında uzman kişiler, ev içerisinde yapılabilecek aktiviteler ya da yeni rutinler oluşturma konusunda yol gösterici bilgiler sunmuştur (Karaaslan, 2020). COVID-19 özellikle yoksulluk yaşayan ve dezavantajlı durumda bulunan küçük çocuklar ve aileleri için büyük bir tehdit oluşturmaktadır (Andrew vd., 2020). Yeni süreç çocukların günlük rutinlerinde büyük oranda değişiklikler meydana getirmiştir. Sosyal anlamda daha öncesinde farklı hayatlara sahip bireyler ev içerisinde tüm zamanlarını birlikte geçirmeye başlamışlardır. Bu değişiklikler ev içerisinde çocuk ve aile arasındaki etkileşimlerin daha yoğun bir şekilde yaşanmasına da sebep olmuştur (Sağlam ve Kay, 2020). Covid-19 sürecinde çocukların evde kalma süreçlerinin etkilerini inceleyen çalışmalar bulunmaktadır. Mert ve Kesicioğlu (2020) çocukların evde oyun oynamalarına yönelik görüşlerini, Çaykuş ve Çaykuş (2020) çocukların evde kalma sürecindeki psikolojik dayanıklılıklarını artırma ile ilgili yolları açıkladıkları çalışmalar yapmışlardır. Okul öncesi dönem çocuklarının ruh sağlıklarını (Pilan vd., 2021), davranış değişikliklerini (Tarkoçin vd., 2020), pandemi sürecinde çocukluk dönemi korkuları (Alisinanoğlu vd., 2020) araştırılmıştır fakat "Evde Kal” sürecinde Covid-19 sürecinde okul öncesi dönem çocukların günlük yaşantılarını ortaya koyan bir çalışma bulunmamaktadır. Bu araştırmada COVID-19 “evde kal” sürecinin anne görüşlerine göre okul öncesi dönem çocukların günlük yaşamlarına yansımasının incelenmesi amaçlanmıştır.

\section{Alt Problemler}

1. COVID-19 ile ilgili çocukların soru sorma ve annelerin bu sorular

2. COVID-19 sürecinde çocukların uyku ve beslenme düzenlerinde bozulma olup olmama durumlarının dağılımları nasıldır? 
3. COVID-19 sürecinde çocukların sokağa çıkma yasağına verdiği tepkilerin dağılımları nasıldır?

4. COVID-19 sürecinde annelerin çocuklarına aldıkları oyuncak, kitap ya da materyallerin dağılımları nasıldır?

5. Çocukların COVID-19 salgınını öğrendikleri kaynakların dağılımları nasıldır?

6. Annelerin COVID-19 sürecinde uzaktan eğitimde zorlandıkları durumların dağılımları nasıldır?

7. COVID-19 sürecinde annelerin çocuklarının hareket etme ihtiyaçlarını karşılama durumlarının dağılımları nasıldır?

\section{Yöntem}

COVID-19 “evde kal” sürecinin anne görüşlerine göre küçük çocukların günlük yaşamlarına yansımasının incelendiği bu çalışma betimsel araştırma niteliğindedir. Araştırmada tarama modeli kullanılmıştır. Tarama modelleri, var olan şekliyle bir durumun betimlenmesini amaçlayan araştırma yaklaşımları olarak tanımlanırlar. Bu model; olayların, grupların, objelerin, çeşitli alanların ve kurumların ne olduklarını betimleyen ve açıklayan araştırmalarda kullanılmaktadır (Karasar, 2005).

\section{Çalışma Grubu}

Araştırmanın çalışma grubunu Bayburt ilinde okul öncesi dönem 5 yaş 137 çocuk ve anneleri oluşturmaktadır. Araştırmanın çalışma grubu tüm birimlere seçilmede eşit şans verdiği için basit tesadüfi örnekleme yöntemi ile belirlenmiştir. Araştırmaya katılan çocuklara ilişkin bilgiler Tablo 2'de, annelere ilişkin bilgiler Tablo 3'te gösterilmiştir.

Tablo 2. Çalışma grubundaki okul öncesi dönem 5 yaş çocukların cinsiyetlerine göre yüzde ve frekans dağılımları yuzde ve frekans daghmlar

\begin{tabular}{lcc}
\hline Çocukların Cinsiyeti & $\mathrm{f}$ & $\%$ \\
\hline Kiz & 70 & 51,1 \\
Erkek & 67 & 48,9 \\
Toplam & 137 & 100,0 \\
\hline
\end{tabular}

Tablo 2 incelendiğinde araştırmaya katılan 137 çocuğun \%51,1'ini $(n=70)$ kızların, \%48,9'unu erkeklerin oluşturulduğu görülmektedir. 
Tablo 3. Çalışma grubundaki annelere ilişkin demografik bilgiler

\begin{tabular}{llcc}
\hline & Demografik Bilgiler & $\mathrm{f}$ & $\%$ \\
\hline Yaş & $20-28$ & 29 & 21,2 \\
& $29-37$ & 81 & 59,1 \\
& 38 ve üstü & 27 & 19,7 \\
& Toplam & 137 & 100,0 \\
\hline \multirow{2}{*}{ Çocuk Sayısı } & Tek çocuk & 36 & 26,3 \\
& İki çocuk & 66 & 48,2 \\
& Üç ve daha fazla çocuk & 35 & 25,5 \\
& Toplam & 137 & 100,0 \\
\hline Eğitim Durumu & İlkokul & 19 & 13,9 \\
& Ortaokul & 19 & 13,9 \\
& Lise & 37 & 27,0 \\
& Üniversite & 62 & 45,3 \\
& Toplam & 137 & 100,0 \\
\hline \multirow{2}{*}{ Çalışma Durumu } & Çalışıyor & 56 & 40,9 \\
& Çalışmıyor & 81 & 59,1 \\
& Toplam & 137 & 100,0 \\
\hline
\end{tabular}

Tablo 3 incelendiğinde çalışma grubundaki 137 annenin \%21'i $(n=29) 20$ 28 yaş aralığında, \%59,1'i $(n=81) 29-37$ yaş aralığında, \%19,7'si $(n=27) 38$ ve üstü yaş aralığındadır. Bu annelerin \%26,3'ü $(n=36)$ tek çocuk sahibi, $\% 48,2$ 'si (n=66) iki çocuk sahibi ve \%25,5'i üç ve daha fazla çocuk sahibidir. $\% 13,9$ 'u $(n=19)$ ilkokul mezunu, \%13,9'u $(n=19)$ ortaokul mezunu, $\% 27,0$ 'si $(n=37)$ lise mezunu ve $\% 45,3$ 'ü $(n=62)$ üniversite mezunudur. Annelerin \%40,9'u (n=56) gelir getirici bir işte çalışırken \%59, 1'i (n=81) gelir getirici bir işte çalışmamaktadır.

\section{Veri Toplama Aracı}

Verilerin toplanmasında araştırmacılar tarafından geliştirilen çevrimiçi anket formu kullanılmıştır. COVID-19 salgınında kısıtlamaların getirilmesinin ardından bu sürecin çocuklara etkileri ve sürecin yönetilmesi ile ilgili alanında uzman kişilerin "Youtube" üzerinden verdiği röportajlar izlenerek Çevrimiçi Anket Formu oluşturulmuştur (Güneş, 2020). Oluşturulan 
Çevrimiçi Anket Formunun kapsam geçerliliğini arttırmak için okul öncesi eğitim alanında çalışan üç akademisyenden uzman görüşü alınmıştır. 10 kişi ile pilot çalışması yapılan Çevrimiçi Anket Formuna son hali verilmiştir. Çevrimiçi Anket Formu, çocuklar ve anneler ile ilgili demografik bilgiler ile COVID-19 “evde kal” sürecinin anne görüşlerine göre küçük çocukların günlük yaşamlarına yansımasını incelemek için oluşturulmuş sorulardan oluşmaktadır.

1. Çocuğunuz COVID-19 ile ilgili sorular soruyor mu?

2. Çocuğunuzun COVID-19 ile ilgili sorduğu sorularına cevap verirken kendinizi yeterli hissediyor musunuz?

3. COVID-19 sürecinde çocuğunuzun uyku düzeni bozuldu mu?

4. COVID-19 sürecinde çocuğunuzun beslenme düzeni bozuldu mu?

5. COVID-19 sürecinde çocuğunuz sokağa çıkma yasağına nasıl tepki verdi?

6. COVID-19 sürecinde çocuğunuza herhangi oyuncak/materyal/kitap aldınız mı? Aldıysanız nelerdir?

7. Çocuğunuz COVID-19 salgınını ilk kimden öğrendi?

8. COVID-19 sürecinde uzaktan eğitimi yeterli buluyor musunuz?

9. COVID-19 sürecinde uzaktan eğitimde zorlanıyor musunuz? Cevabınız evetse hangi konularda zorlanıyorsunuz?

10. COVID-19 sürecinde çocuğunuzun hareket etme ihtiyacını karşılayabildiniz mi? Cevabınız evetse hareket etme ihtiyacını nasıl karşıladınız?

\section{Verilerin Toplanmasi}

Çevrimiçi Görüşme Formu oluşturulduktan sonra sorular "Google Formlar'a" yüklenmiştir. Çevrimiçi Anket Formu sokağa çıkma kısıtlamalarının uygulanmaya başlamasının üzerinden belli bir zaman geçtikten, çocukların günlük rutinleri belirli düzeyde değiştikten sonra aileler tarafindan 26 Haziran 2020 tarihinden itibaren doldurulmaya başlanmıştır. Oluşturulan Çevrimiçi Anket Formu Bayburt ili bağımsız anaokulu ve ilkokul müdürlerine gönderilmiştir. Müdürler, Çevrimiçi Anket Formunun bağlantı adresini öğretmenler aracılığı ile ailelere iletmiştir. 155 kişi Çevrimiçi Anket Formu'nu doldurmuştur. Anneler dışındaki kişiler tarafından doldurulan ve eksik bilgiler veren formlar araştırma kapsamına 
alınmamıştır. Araştırmaya 137 anne ve 137 çocuk dahil edilmiştir. Veriler, Çevrimiçi Anket Formu'ndan Microsoft Excel programına aktarılmıştır. Microsoft Excel ile elde edilen veriler "SPSS 22.0" paket programina aktarılmıştır.

\section{Verilerin Analizi}

Çevrimiçi Görüşme Formu ile elde edilen bilgiler betimsel analiz yöntemi kullanılarak çözümlenmiştir. Betimsel analiz, araştırma sorularından elde edilen verilerin ortaya çıkan temalar altında organize edilip sunulduğu yaklaşımdır (Yıldırım ve Şimşek, 2003).

\section{Bulgular}

Çalışmanın bu kısmında araştırma verilerinin çözümlenmesiyle elde edilen bulgular araştırmanın alt problemleri sırasına bağlı kalınarak sunulmuştur.

Tablo 4'te çocukların Covid-19 ile ilgili ailelerine soru sorma durumlarının dağılımı gösterilmiştir.

Tablo 4. Çocukların COVID-19 ile ilgili soru sorma durumlarının yüzde ve frekans dağılımları

\begin{tabular}{lcc}
\hline $\begin{array}{l}\text { Çocuğun COVID-19 ile ilgili } \\
\text { soru sorma durumu }\end{array}$ & $\mathrm{f}$ & $\%$ \\
\hline Sorular soruyor. & 119 & 86,9 \\
Herhangi bir soru sormuyor. & 18 & 13,1 \\
Toplam & 137 & 100,0 \\
\hline
\end{tabular}

Tablo 4'e göre çocukların \%86,9'unun COVID-19 ile ilgili sorular sorduğu, \%13,1'inin süreçle ilgili sorular sormadığı görülmektedir.

Tablo 5'de çocukların COVID-19 ile ilgili sordukları sorulara annelerin yanıt verirken kendilerini yeterli hissetme durumlarının yüzde ve frekans dağılımları gösterilmiştir. Tablo 4'de görüldüğü üzere 137 çocuktan 119'u Covid-19 ile ilgili soru sorduğundan dolayı bu tabloda 119 katılımcı gösterilmiştir. 
Tablo 5. Çocukların COVID-19 ile ilgili sordukları sorulara annelerin yanıt verirken kendilerini yeterli hissetme durumlarının yüzde ve frekans dağılımları

\begin{tabular}{lcc}
\hline $\begin{array}{l}\text { Annenin sorulara yantt vermede kendini } \\
\text { yeterli hissetme durumu }\end{array}$ & $\mathrm{f}$ & $\%$ \\
\hline Yeterli hissediyorum & 45 & 37,8 \\
Bazen yeterli bazen yetersiz hissediyorum & 67 & 56,3 \\
Yetersiz hissediyorum & 7 & 5,9 \\
Toplam & 119 & 100,0 \\
\hline
\end{tabular}

Tablo 5'e göre annelerin \%37,8'i $(n=45)$ çocukların sordukları soruları yanıtlamada kendilerini yeterli hissettiği, \%56,3'ünün $(n=67)$ kısmen yeterli hissettiği ve \%5,8'inin ( $n=7)$ kendini yetersiz hissettiği görülmektedir.

Tablo 6'da COVID-19 sürecinde çocukların uyku düzenlerinin bozulma durumlarının yüzde ve frekans dağılımları gösterilmiştir.

Tablo 6. COVID-19 sürecinde çocukların uyku düzenlerinin bozulma durumlarının yüzde ve frekans dağılımları

\begin{tabular}{lcc}
\hline $\begin{array}{l}\text { Çocuğun uyku düzeninin } \\
\text { bozulma durumu }\end{array}$ & $\mathrm{f}$ & $\%$ \\
\hline Uyku düzeni bozulmadı. & 53 & 38,7 \\
Uyku düzeni bozuldu. & 84 & 61,3 \\
Toplam & 137 & 100,0 \\
\hline
\end{tabular}

Tablo 6 incelendiğinde çocukların \%61,3'ünün $(n=84)$ uyku düzeninin bozulduğu, \%38,7'sinin uyku düzeninin bozulmadığı görülmektedir.

Tablo 7'de COVID-19 sürecinde çocukların beslenme düzenlerinin bozulma durumlarının yüzde ve frekans dağılımları gösterilmiştir.

Tablo 7. COVID-19 sürecinde çocukların beslenme düzenlerinin bozulma durumlarının yüzde ve frekans dağılımları 
Tablo 8'de COVID-19 sürecinde çocukların sokağa çıkma yasağına verdikleri tepkilerin yüzde ve frekans dağılımları gösterilmiştir.

Tablo 8. COVID-19 sürecinde çocukların sokağa çıkma yasağına verdikleri tepkilerin yüzde ve frekans dağılımları

\begin{tabular}{llcc}
\hline Tepkiler & & $\mathrm{f}$ & $\%$ \\
Olumsuz Tepkiler & Üzülme & 29 & 21,2 \\
& Bunalma & 15 & 10,9 \\
& Kızma & 7 & 5,1 \\
& Sıkılma & 6 & 4,4 \\
& Korkma & 3 & 2,2 \\
Olumlu Tepki & Uyuma yönelik tepkiler & 13 & 9,5 \\
& Anlayışla karşılama & 45 & 32,8 \\
Değişkenlik & Değişken tepkiler & 8 & 5,8 \\
Tepkisizlik & Tepkisiz kalma & 7 & 5,1 \\
& Toplam & 137 & 100,0 \\
\hline
\end{tabular}

Tablo 8 verilerine bakıldığında çocukların \%21,2'si $(n=29)$ üzülerek, \%10,9'u bunalımla, \%5,1'i $(n=7)$ kızarak, \%4,4'ü $(n=6)$ sıkılarak, \%2.2'si $(n=3)$ korkarak olumsuz tepkiler vermiştir. Çocukların \%32,8'i $(n=45)$ durumu anlayışla karşılamış, \%9,5'i $(n=13)$ uyuma yönelik tepkiler vermiş, \%5,8'i $(n=8)$ değişken tepkiler sergilemiş ve \%5,1'i $(n=7)$ tepkisiz kalmıştır.

Tablo 9'da annelerin COVID-19 sürecinde çocuklarına oyuncak, materyal ve kitap alıp almama durumlarının yüzde ve frekans dağılımları gösterilmiştir.

Tablo 9. Annelerin COVID-19 sürecinde çocuklarına oyuncak, materyal ve kitap alıp almama durumlarının yüzde ve frekans dağılımları

\begin{tabular}{lcc}
\multicolumn{3}{c}{ almama durumlarının yüzd } \\
\hline Alıp Almama & $\mathrm{f}$ & $\%$ \\
\hline Evet & 119 & 86,9 \\
Hayır & 18 & 13,1 \\
Toplam & 137 & 100,0 \\
\hline
\end{tabular}

Tablo 9'da görüldüğü üzere annelerin \%86,9'u (119) COVID-19 sürecinde çocuklarına oyuncak, materyal ya da kitap almış, \%13,1'i $(n=18)$ ise almamıştır. 
Tablo 10'da annelerin COVID-19 sürecinde çocuklarına aldıkları oyuncak, materyal ve kitapların yüzde ve frekans dağılımları gösterilmiştir.

Tablo 10. Annelerin COVID-19 sürecinde çocuklarına aldıkları oyuncak, materyal ve kitapların yüzde ve frekans dağılımları

\begin{tabular}{lcc}
\hline Alınanlar & $\mathrm{f}$ & $\%$ \\
\hline Kitap & 95 & 46,6 \\
Oyuncak & 47 & 23,0 \\
Eğitici Oyun & 44 & 21,6 \\
Etkinlik Materyali & 18 & 8,8 \\
Toplam & 204 & 100,0 \\
\hline
\end{tabular}

Tablo 10 incelendiğinde çocuğuna oyuncak, materyal ya da kitap aldığını belirten 119 annenin 95'i kitap (\%46,6), 44'ü eğitici oyun $(\% 21,6), 47$ 'si oyuncak $(\% 23,0)$ ve 18 'i etkinlik materyali $(\% 8,8)$ almıştır.

Tablo 11'de annelerin COVID-19 sürecinde çocuklarına aldıkları oyuncak, materyal ve kitapların türlere göre yüzde ve frekans dağılımları gösterilmiştir.

Tablo 11. Annelerin COVID-19 sürecinde çocuklarına aldıkları oyuncak, materyal ve kitapların türlere göre yüzde ve frekans dağılımları

\begin{tabular}{|c|c|c|c|}
\hline & Alınanların Türlere Göre Dağılımları & $\mathrm{f}$ & $\%$ \\
\hline \multirow{8}{*}{ 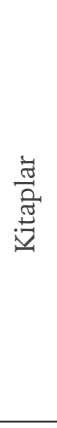 } & Boyama Kitabı & 22 & 23,2 \\
\hline & Hikaye Kitabı & 48 & 50,5 \\
\hline & Dikkat Seti & 8 & 8,4 \\
\hline & Çocuk Dergisi & 2 & 2,1 \\
\hline & Etkinlik Kitabı & 11 & 11,6 \\
\hline & Kodlama Kitabı & 2 & 2,1 \\
\hline & Masal Kitabı & 2 & 2,1 \\
\hline & Toplam & 95 & 100,0 \\
\hline \multirow{5}{*}{ 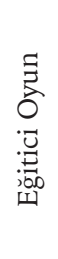 } & Kutu Oyunları & 19 & 43,2 \\
\hline & Yapboz & 17 & 38,6 \\
\hline & Lego & 5 & 11,4 \\
\hline & Zeka Kartları & 3 & 6,8 \\
\hline & Toplam & 44 & 100,0 \\
\hline
\end{tabular}




\begin{tabular}{|c|c|c|c|}
\hline \multirow{4}{*}{ 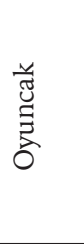 } & Bebek & 10 & 21,3 \\
\hline & Hareket için oyuncaklar(bisiklet, scooter, salıncak, top) & 13 & 27,7 \\
\hline & $\begin{array}{l}\text { Oyun için oyuncaklar (doktor seti, evcilik seti, asker, } \\
\text { çeşitli oyuncaklar) }\end{array}$ & 24 & 51,0 \\
\hline & Toplam & 47 & 100,0 \\
\hline \multirow{3}{*}{ 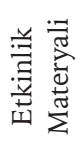 } & Malzeme (yapıştırıcı, makas, boya kalemi) & 9 & 50,0 \\
\hline & Oyun hamuru & 9 & 50,0 \\
\hline & Toplam & 18 & 100,0 \\
\hline
\end{tabular}

Tablo 11'e göre alınan kitapların \%23,2'sini $(\mathrm{n}=22)$ boyama kitapları, $\% 50,5$ 'ini $(n=48)$ hikaye kitapları, \%8,4'ünü $(n=8)$ dikkat setleri, \%2,1'ini $(n=2)$ çocuk dergileri, \%11,6'sını $(n=11)$ etkinlik kitapları, \%2.1'ini kodlama kitapları ve \%2,1'ini $(n=2)$ masal kitapları oluşturmaktadır. Eğitici oyunların \%43,2'sini $(n=19)$ kutu oyunları, \%38,6'sını $(n=17)$ yapbozlar, \%11,4'ünü $(n=5)$ Legolar, \%6,8'ini zeka kartları $(n=3)$ oluşturmaktadır. Oyuncakların \%21,3'ünü $(n=10)$ bebekler, \%27,7'sini $(n=13)$ hareket için olan oyuncaklar, \%51'ini oyun için olan oyuncaklar oluşturmaktadır. Etkinlik materyallerinin \%50'sini $(n=9)$ malzemeler, \%50'sini $(n=9)$ oyun hamuru oluşturmaktadır.

Tablo 12'de çocukların COVID-19 salgınını öğrendiği kaynakların yüzde ve frekans dağılımları gösterilmiştir.

Tablo 12. Çocukların COVID-19 salgınını öğrendiği kaynakların yüzde ve frekans dağılımları

\begin{tabular}{lccc}
\hline Çocuğun COVID-19 Salgınını Öğrendiği Kaynaklar & f & $\%$ \\
\hline Anne Baba & 100 & 73,0 \\
Öğretmen & 16 & 11,7 \\
Televizyon & 15 & 11,0 \\
Ailedeki kişilerin kendi aralarındaki konuşmalardan & 4 & 2,9 \\
Aile dışındaki kişilerden & 1 & 0,7 \\
Kimden öğrendiği tam olarak bilinmeyen & 1 & 0,7 \\
Toplam & 137 & 100,0 \\
\hline
\end{tabular}

Çocuk ve Medeniyet 2021/1
Tablo 12'de çocukların \%73'ünün (n=100) COVID-19 salgınını annebabasından öğrendiği, \%11,7'sinin (n=16) öğretmeninden öğrendiği, 
\%11'inin televizyondan öğrendiği, \%2,9'unun ailedeki kişilerin kendi aralarındaki konuşmalarından öğrendiği, \%0,7'sinin aile dışındaki kişilerden öğrendiği ve \%0,7'sinin kimden olduğu bilinmeyen bir kaynaktan öğrendiği görülmektedir.

Tablo 13'de COVID-19 sürecinde annelerin uzaktan eğitim yeterli bulma durumlarının yüzde ve frekans dağılımları gösterilmiştir.

Tablo 13. COVID-19 sürecinde annelerin uzaktan eğitim yeterli bulma durumlarının yüzde ve frekans dağılımları

\begin{tabular}{lcc}
\hline Annelerin uzaktan eğitimi yeterli bulma durumları & N & $\%$ \\
\hline Yeterli değil & 99 & 72,3 \\
Yeterli & 38 & 27,7 \\
Toplam & 137 & 100,0 \\
\hline
\end{tabular}

Tablo 13 incelendiğinde annelerin \%72,3'ü $(n=99)$ COVID-19 sürecinde okul öncesi eğitimi yeterli bulmamaktadır. \%27,7'si bu süreçteki eğitimi yeterli bulmaktadır.

Tablo 14'de annelerin COVID-19 sürecinde uzaktan eğitimde zorlanma durumlarının yüzde ve frekans dağılımları gösterilmiştir.

Tablo 14. Annelerin COVID-19 sürecinde uzaktan eğitimde zorlanma durumlarının yüzde ve frekans dağılımları

\begin{tabular}{lcc}
\hline Zorlanma Durumu & $\mathrm{f}$ & $\%$ \\
\hline Zorlandık & 100 & 73,0 \\
Zorlanmadık & 29 & 21,2 \\
Uzaktan Eğitim Alamadık & 8 & 5,8 \\
Toplam & 137 & 100,0 \\
\hline
\end{tabular}

Tablo 14 incelendiğinde annelerin \%73'ü COVID-19 sürecinde uzaktan eğitimde zorlanmış, \%21,2'si $(n=29)$ zorlanmamış ve \%5,8'i $(n=8)$ uzaktan eğitim almamıştır. 
Tablo 15'de annelerin COVID-19 sürecinde zorlandıkları konuların yüzde ve frekans dağılımları gösterilmiştir.

Tablo 15. Annelerin COVID-19 sürecinde zorlandıkları konuların yüzde ve frekans dağılımları

\begin{tabular}{lcc}
\hline Zorlanılan Konular & $\mathrm{f}$ & $\%$ \\
\hline Etkinlik yaptırma & 26 & 26,0 \\
Çocuğun dikkatini toplama & 14 & 14,0 \\
Çocuğun isteksizliği & 11 & 11,0 \\
İnternet alt yapı yetersizliği & 10 & 10,0 \\
Etkinlikleri anlama ve çocuğa anlatma & 9 & 9,0 \\
Sürecin genel olarak zorlaması & 6 & 6,0 \\
Uzaktan eğitime adapte olma konusundaki sorunlar & 6 & 6,0 \\
Zamanla ilgili sorunlar & 4 & 4,0 \\
Çocukla iletişim kurmada yaşanan sorunlar & 4 & 4,0 \\
Materyal temin etme & 4 & 4,0 \\
Çocuğu teknolojik araçlardan uzak tutma & 4 & 4,0 \\
Çocuğa hareket alanı sağlama & 2 & 2,0 \\
Toplam & 100 & 100,0 \\
\hline
\end{tabular}

COVID-19 sürecinde uzaktan eğitimde zorlandığını söyleyen 100 annenin zorlandıkları konular Tablo 15'de gösterilmiştir. Bu annelerin \%10'u $(n=10)$ alt yapıdan , \%14'ü $(n=14)$ çocuğun dikkatini toplamaktan, \%6'sı $(n=6)$ süreçten genel olarak zorlanmaktan, \%9'u etkinlikleri anlama ve çocuğa anlatmaktan, \%26'sı $(n=26)$ çocuklara etkinlikleri yaptırmaktan, \%4'ü $(n=4)$ zamanla ilgili sorunlardan, \%11'i $(n=11)$ çocuğun isteksizliğinden, \%6'sı uzaktan eğitime uyum sağlama konusundaki sorunlardan, \%4'ü $(n=4)$ çocukla iletişim kurmada yaşanan sorunlardan, \%4'ü $(n=4)$ materyal temin etmekten, \%2'si $(n=2)$ çocuğa hareket alanı sağlamaktan ve \%4'ü $(n=4)$ çocuğu teknolojik araçlardan uzak tutmaktan kaynaklı konularda sorun yaşadıklarını belirtmişlerdir.

Tablo 16'da COVID-19 sürecinde annelerin çocukların hareket etme ihtiyaçlarını karşılama durumlarının yüzde ve frekans dağılımları 
Tablo 16. COVID-19 sürecinde annelerin çocukların hareket etme ihtiyaçlarını karşılama durumlarının yüzde ve frekans dağılımları

\begin{tabular}{lcc}
\hline Hareket ihtiyacını karşılama durumu & $\mathrm{f}$ & $\%$ \\
\hline Karşılayabildim & 126 & 92,0 \\
Karşılayamadım & 11 & 8,0 \\
Toplam & 137 & 100,0 \\
\hline
\end{tabular}

Tablo 16 incelendiğinde annelerin \%92'si $(n=126)$ çocukların hareket etme ihtiyaçlarını karşılayabilmiş, \%8'i $(n=11)$ çocuğun hareket etme ihtiyacını karşılayamamıştır.

Tablo 17'de COVID-19 sürecinde annelerin çocukların hareket etme ihtiyaçlarını karşılama şekilleri gösterilmiştir.

Tablo 17. COVID-19 sürecinde annelerin çocukların hareket etme ihtiyaçlarını karşılama şekilleri

\begin{tabular}{lcc}
\hline Hareket etme ihtiyacını karşılama şekli & $\mathrm{f}$ & $\%$ \\
\hline Evde Oyun oynayarak & 49 & 38,9 \\
Evin bahçesine/evin terasına/sitenin bahçesine çıkararak & 25 & 19,9 \\
Spor/ Doğa yürüyüşü yaparak & 22 & 17,4 \\
Hareket alanları sağlayarak & 11 & 8,7 \\
Parka giderek & 6 & 4,8 \\
Hareket sağlayan araçlarla (scooter, bisiklet, oyuncak at) & 5 & 4,0 \\
Kardeşi ile vakit geçirmesini sağlayarak & 5 & 4,0 \\
Ev işlerinde görev vererek & 3 & 2,3 \\
Toplam & 126 & 100,00 \\
\hline
\end{tabular}

Tablo 17 incelendiğinde annelerin 38,9'u $(n=49)$ evde oyun oynayarak, $\% 17,4$ 'ü $(n=22)$ spor/doğa yürüyüşü yaparak, \%19,9'u $(n=25)$ evin bahçesine/evin terasına/ sitenin bahçesine çıkararak, \%4,8'i $(n=6)$ parka giderek, \%2,3'ü ev işlerinde görev vererek, \%8,7'si $(n=11)$ hareket alanları sağlayarak, \%4'ü $(n=5)$ hareket sağlayan araçlarla (scooter, bisiklet, oyuncak at) ve \%4'ü $(n=5)$ kardeşi ile vakit geçirmesini sağlayarak çocuklarının hareket etme ihtiyaçlarını karşılamışlardır. 


\section{Tartışma ve Öneriler}

Bu çalışma kapsamında, sokağa çıkma yasaklarının yoğun olarak yaşandığı Nisan ve Haziran 2020 ayları arasında beş yaş çocukların uyum süreçleri, eğitim durumları, ev yaşamları çeşitli açılardan ele alınmıştır. Araştırmada, küçük çocukların önemli bir bölümünün COVID-19 ile ilgili soru sordukları, konu ile ilgilendikleri görülmektedir. COVID-19, küçük çocukların hayatını akranlarından, öğretmenlerinden uzak kalmalarına ve izolasyon sonucunda evden çıkamamalarına sebep olarak, doğrudan ve ciddi bir şekilde değiştirmiştir (UNICEF, 2020a). Küçük çocuklar gerek kendi yaşamlarındaki değişiklikler gerekse çevreyle ilgili gözlemleri sonucunda COVID-19 sürecini ve beraberinde getirdiği maske, dezenfektan, sosyal mesafe gibi kavramları merak etmişlerdir.

$\mathrm{Bu}$ araştırmadaki annelerin çoğunluğu COVID 19 ile ilişkili sorular karşısında kendini bazen yeterli bazen yetersiz hissettiğini ifade etmiştir. Konu ile ilgili yapılan çeşitli araştırmalarda da COVID 19'un ailelerin iyi oluş durumlarını olumsuz yönde etkileyebildiği, ebeveynlerin öz yeterliklerinde düşüş olabildiği ortaya konulmuştur (Prime vd., 2020).

Küçük çocukların rutinlerine bakıldığında çoğunluğunun uyku düzeninin bozulduğu, yemek düzeninin ise bozulmadığı görülmektedir. Ancak Carroll vd. (2020) orta ve üst düzey gelire sahip Kanadalı aileler ile yaptıkları çalışmalarında ailelerin yarısından fazlası çocuklarının beslenme düzeninin bozulduğunu bildirmiştir. Beslenme düzenindeki değişiklikte en büyük sorunu ise abur cubur tüketimindeki artış olarak göstermişlerdir. Uyku düzeni ile ilgili alanyazında yapılan çalışmalar ise farklılıklar göstermektedir. Liu vd. (2020) COVID-19 sürecinde çocukların gerçekten uyku düzenlerinin bozulup bozulmadığını inceledikleri çalışmalarında aynı çocuklardan 2018 yılında elde ettikleri veriler ile COVID-19 sürecinde elde ettikleri verileri karşılaştırdıklarında bir farklılık bulunmadığını belirlemişlerdir. COVID-19 sürecinde çocukların uyku düzenlerinin bozulduğunu ortaya koyan ilk çalışma ise Lecuelle vd. (2020) tarafından yapılmıştır.

Çocukların sokağa çıkma yasağına karşı olumsuz, olumlu ve diğer olmak üzere üç tür tepki geliştirdiği ortaya konulmuştur. Olumsuz tepkiler beş tepki türü ile en çeşitlilik gösteren tepki türüdür. Olumlu ve olumsuz tepkiler oran açısından birbirine yakın iken çocukların değişken tepkiler gösterebildikleri ve tepkisiz de kalabildikleri ortaya konulmuştur. Çocuklar olumsuz tepkilerde en çok üzülmüş, olumlu tepkilerde de en çok anlayışla karşılamıştır. Saurabh ve Ranjan (2020) kısıtlamalara maruz kalan çocukların en çok yaşadıkları duyguları; endişe, çaresizlik ve korku olarak bulmuşlardır. COVID-19 dönemindeki bazı çalışmalar, küçük çocukların 
günlük hayatındaki kaygıda artış olduğunu ifade etmektedir (Howes vd., 2020; Singh vd., 2020). Ayrıca küçük çocukların hayatında akranlarının ve öğretmenlerinin önemi göz önünde bulundurulduğunda (Erbay ve Durmuşoğlu Saltalı, 2020; Howes, 2001), okul öncesi eğitimden uzak kalmanın çocukları sosyal ve duygusal açıdan oldukça zorlayabileceği kendiliğinden ortaya çıkmaktadır. İki-yedi yaş arası çocuğu olan 351 İsrailli aile ile yapılan bir çalışmada (Shorer ve Leibovich, 2020), COVID-19 sürecinde çocukların en sık kaygı, saldırganlık, ayrılık kaygısı, anne-babanın yanından ayrılmama şeklinde tepkiler geliştirdiği ifade edilmektedir. Pascal ve Bertham (2021), İngiltere, İskoçya ve Yeni Zelanda'da yaşayan okul öncesi dönem çocuklarıyla yaptıkları çalışmada, çocukların COVID 19 deneyimleri sonucunda en çok arzu ettikleri şeylerin günlük hayata ve rutinlere geri dönmek, arkadaşlarıyla vakit geçirmek, daha uzun süre oyun oynamak ve açık alana çıkmak olduğunu ortaya koymuştur.

Annelerin büyük bir çoğunluğu COVID 19 sürecinde çocuklarına oyuncak, materyal ve kitap gibi ürünlerden almıştır. Alınan ürünlerin içinde kitaplar önemli bir çoğunluğu oluşturmaktadır. Kitaplardan en çok hikâye kitabı, eğitici oyunlardan ise en çok kutu oyunları tercih edilmiştir. Oyuncakta doktor/evcilik seti, asker gibi çok parçalı oyuncaklar alınmıştır. Etkinlik malzemesi olarak da oyun hamuru, boya gibi malzemeler tercih edilmiştir. $\mathrm{Bu}$ araştırmada yer alan annelerin, çocuklarının eğitici ürünlerle zaman geçirmesine yönelik çaba sarf ettikleri söylenebilir. UNICEF (2020b) konu ile ilgili olarak hazırladığı bir kitapçıkta anne-babalara çocuklarıyla kaliteli zaman geçirme açısından hareketli oyunları, kart oyunlarını, hikaye okumayı, şarkı söylemeyi, nesnelerde değişiklik yapma gibi yaratıcılığa dönük oyunları tavsiye etmiştir.

Okul öncesi dönem çocukların önemli bir çoğunluğunun COVID 19'u annebabasından öğrendiği belirlenirken, çocukların bilgi kaynaklarının öğretmen, televizyon, aile çevresi, aile dışındaki kişiler ve bilinmeyen kaynak şeklinde çeşitlilik gösterebildiği ortaya konulmuştur. Anne-babalar, özellikle okul öncesi dönem çocuğunun hayatında bilgi kaynağı olarak da çok büyük bir etkiye sahiptir (Kırman ve Doğan, 2017).

Annelerin büyük bir çoğunluğu, çevrimiçi eğitimi yetersiz bulurken, çevrimiçi eğitim sürecinde zorlandığını da ifade etmiştir. Hong Kong'da \%93'ü anne olan 6702 ebeveyn ile gerçekleştirilen bir çalışmada (Lau ve Lee, 2020), çocukların büyük bir bölümünde çevrimiçi eğitim sürecine ilgisizlik, öğrenmeye yönelik motivasyon düşüklüğü görülmüş ve ev ortamındaki yetersizliklerin çevrimiçi / uzaktan eğitimi zorlaştırabildiği ortaya konulmuştur. Aynı çalışmada, ebeveynler çevrimiçi/uzaktan eğitimde 
daha etkileşime dayalı yöntemlerin kullanılmasını, eğitim saatlerinde esnekliğin olmasını talep etmişlerdir (Lau ve Lee, 2020).

Bu çalışmada, annelerin bu süreçte uzaktan eğitimde en çok zorlandıkları konu, çocuğa etkinlik yaptırmak olmuştur. Bunun yanı sıra annelerin internet alt yapısı gibi çevresel koşullar açısından ve çocuğa etkinlikleri anlatma, çocukla iletişim kurma gibi kendilerinden de kaynaklanabilecek konularda da zorlanabildikleri görülmüştür. Putri vd. (2020) yaptıkları çalışmalarında ebeveynlerin uzaktan eğitimde en çok zorlandıkları durumları; çocukların evde çalışma disiplinin olmaması ve evde öğretim yapabilmek için normalden çok daha uzun süre harcamaları olarak belirtmişlerdir.

Bu sonuçlar doğrultusunda, çalışma grubundaki anneler için COVID 19 sürecinde, çocuk, çevresel şartlar, var olan durumun ortaya koyduğu durumlar, ekonomik şartlar ve bireysel yeterlilikleri gibi geniş bir konu ağında zorlanabildikleri söylenebilir. Anneler zorlandıkları durumların çeşitlilik gösterdiğini ifade etmelerine karşılık, büyük bir çoğunluğu çocuğunun ev içinde hareket ihtiyacını karşılayabildiğini ifade etmiştir. Anneler, çocuklarının hareket ihtiyacını karşılamada en sık yararlandıkları stratejinin onlarla oyun oynamak olduğunu ifade etmişlerdir. COVID-19, Dünya genelindeki her yaş grubundan bireyin iş, eğitim, aile başta olmak üzere tüm günlük yaşamını çeşitli şekillerde etkilemiştir (Priyadharsini ve Chiang, 2020). Anne-babalar, bu süreçte özel yaşamlarında uyumu sağlamaya çalışırken çocuklarıyla ilgili COVID-19 öncesinden daha büyük sorumluluklar almak durumunda kalmışlardır. Örnek olarak, var olan süreçle ilgili doğru bilgiyi sağlayabilmek ve eğitim faaliyetlerinin kesintisiz bir şekilde devamını sağlamak için çocukları için bir eğitimci, duygusal sağlığını koruyabilmeleri için rehber ve yaşam koçu; oyun ve eğlence ihtiyacını gidermek için bir arkadaş haline gelmişlerdir. Bahsedilen bu roller, anne-babalık içerisinde her zaman olabilecek durumlar iken (Erbay ve Saygın, 2020), COVID-19'da daha da iç içe geçmiş, sosyal izolasyon sonucunda sürekli birlikte olunduğu için de yoğunluğu artmıştır. Dolayısıyla anne-babalar COVID-19 sürecinde çok farklı değişkenler arasında dengeyi sağlayıp, rollerinin gereğini en iyi şekilde yapabilme adına her zamankinden fazla çaba sarf edip, zorlanabilmişlerdir (Morelli vd., 2020). Priyadharsini ve Chiang (2020), COVID-19'da ailelerin kendilerini çocuklarının ihtiyaçlarını karşılamakla ilgili yalnız ve bunalmış hissedebildiğini ifade edip ailelere psikolojik destek sunmanın önemine dikkat çekmişlerdir. Oyun açısından, Shorer ve Leibovich, (2020) yaptıkları çalışmada, özellikle babaların oyun oynamayı seven bir yaklaşım içinde olmasının çocuktaki stresi azaltabildiğini ifade etmiştir. Dolayısıyla anne-babaların çocuklarıyla 
kaliteli zaman geçirme, oyun oynama gibi konularda bilgilendirilmeleri çocukla iletişimleri, çocuğun ruh sağlığı, anne-babanın kendisi yeterli hissedebilmesi açısından önemlidir. Toran vd., (2020) Çin ve Türkiye'den aileleri karşılaştırdıkları çalışmalarında hem Türk hem Çinli ebeveynlerin COVID-19 sürecinin evde kalma ile ilgili zorluklarına ve psikolojik etkilerine odaklandıklarını ve ayrıca Çinli ebeveynlerin sosyal izolasyon sürecinin her gün benzer etkinlikler ve faaliyetler yapmak anlamına geldiğini belirttiklerini ortaya koymuşlardır. Çinli aileler hem değişen ebeveynlik rollerine bağlı olarak hem de çok uzun süre evde kalmaktan kaynaklı olarak okul aktiviteleri, yemek pişirme ve oyun oynama gibi etkinlikleri günlük yaşam rutinlerine de dahil etmişlerdir. Amerika'nın beş eyaletinde okul öncesi dönem çocukları ile ilgili yapılan çalışmada aileler kısıtlama sürecinin olumlu yanları olarak kardeşler arasındaki ilişkilerin artması ve aile içinde geçirilen zamandaki olumlu artışı göstermişlerdir (Jones, 2020).

Görüldüğü üzere gerek Türkiye'de gerekse farklı ülkelerde COVID-19 süreci ile ilgili yapılan çalışmalar, küçük çocukların sürece uyum sağlamakta zorlanabildiğini, ailelerin çeşitli nedenlerle zorluklar yaşayabildiğini ortaya koymuştur. Bulgular, ailelere uyum sağlayıcı ve kriz odaklı rehberlik hizmetlerinin verilmesinin, çevrimiçi eğitim ile ilgili gerek alt yapı gerek içerik açısından düzenlemeler yapılmasının önemini göstermektedir. Ayrıca değişen bu günlük yaşam rutinlerinin şu anda ve gelecekte hangi durumları etkileyeceğine dair çalışmalar yapılması önem taşımaktadır. Covid-19 sürecinde okul öncesi dönem çocuklarıyla yapılan çalışmaların meta analizi yapılıp çocukların gelişimlerine etkisi de tespit edilebilir.

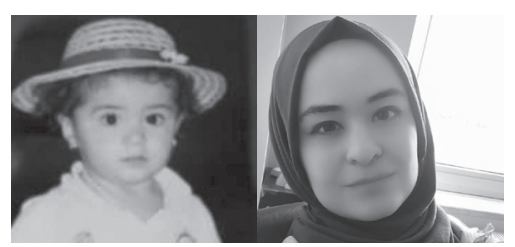

Ceren Arı Arat

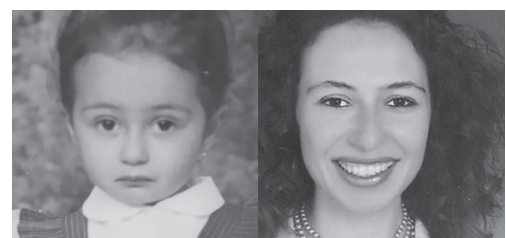

Hülya Gülay Ogelman 


\section{Kaynakça}

Alisinanoḡlu, F., Türksoy, E., \& Karabulut, R. (2020). Pandemi sürecinde çocukluk dönemi korkuları. Uluslararası Beșeri Bilimler ve Eḡitim Dergisi, 6(14), 447-568.

Andrew, A., Cattan, S., Costa-Dias, M., Farquharson, C., Kraftman, L., Krutikova, S., ... \& Sevilla, A. (2020). Learning during the lockdown: real-time data on children's experiences during home learning. London: The Institute for Fiscal Studies.

Bilgin, R., \& Diḡer, H. (2021). Küresel salgın (covıd-19) sürecinde evde yașam tatmini. Alternative Politics/Alternatif Politika, 13(2), 409-438. https://doi.org/10.53376/ap.2021.14

Carroll, N., Sadowski, A., Laila, A., Hruska, V., Nixon, M., Ma, D. W., \& Haines, J. (2020). The impact of COVID-19 on health behavior, stress, financial and food security among middle to high income Canadian families with young children. Nutrients, 12(8), 1-14. https://doi.org/10.3390/ nu12082352

Cağlayan Tunç, A. , Zorba, E. \& Cingöz, Y. E. (2020). Covid 19 salgını döneminde egzersizin yașam kalitesine etkisi. Uluslararası Güncel Eğitim Araștırmaları Dergisi , 6(1) , 127-135.

Caykus, E. T., \& Caykuș, T. M. (2020). Covıd-19 pandemi sürecinde çocukların psikolojik dayanıkılığını güçlendirme yolları: ailelere, öğretmenlere ve ruh saḡlığı uzmanlarına öneriler. Avrasya Sosyal Ve Ekonomi Araștırmaları Dergisi, 7(5), 95-113.

Erbay, F., \& Saltalı, N. D. (2020). Do the school adaptation levels of preschoolers vary according to their relationship with their teachers?. International Journal of Evaluation and Research in Education (IJERE). 9(4), 857-864. http://doi.org/10.11591/ijere.v9i4.20540

Erbay, F., \& Saygın, Y. (2020). Boșanma ve çocuklar. (Ed. H. Gülay Ogelman). Dezavantajlı Cocuklar. (s. 161-180). Ankara: Eğiten Kitap.

Griffith, A. K. (2020). Parental burnout and child maltreatment during the COVID-19 pandemic. Journal of Family Violence , 1-7. https://doi.org/10.1007/s10896-020-00172-2

Günther-Bel, C., Vilaregut, A., Carratala, E., Torras-Garat, S., \& P rez-Testor, C. (2020). A mixed-method study of Individual, couple, and parental functioning during the state-regulated COVID-19 lockdown in Spain. Family process, 59(3), 1060-1079. https://doi.org/10.1111/famp.12585

Howes, C. (2000). Social-emotional classroom climate in child care, child-teacher relationships and children's second grade peer relations. Social Development, 9(2), 191-204. https://doi. org/10.1111/1467-9507.00119

Howes, S., Monk-Winstanley, R., Sefton, T. \& Woudhuysen. A. (2020). Poverty in the pandemicTthe Impact of Coronavirus on low Income families and children. London: Child Poverty Action Group.

Jiao Jiao, W. Y., Wang, L. N., Liu, J., Fang, S. F., Jiao, F. Y., Pettoello-Mantovani, M., \& Somekh, E. (2020). Behavioral and emotional disorders in children during the COVID-19 epidemic. The journal of Pediatrics, 221, 264-266. https://doi.org/10.1016/j.jpeds.2020.03.013

Jones, D. (2020). The impact of COVID-19 on young children, families, and teachers. Defending the Early Years. 1-16. https://files.eric.ed.gov/fulltext/ED609168.pdf

Karaaslan-Sert, Y. (2020). Sosyal izolasyon sürecinde “evde kal saḡlıklı kal”. https://www.aa.com.tr/ tr/saglik/sosyal-izolasyon-surecinde-evde-kal-sporla-saglikli-kal/1801546 [Erișim tarihi: 05 Mart 2021].

Karasar, N. (2005). Bilimsel araștırma yöntemi: kavramlar, ilkeler ve teknikler. Ankara: Nobel Yayıncılık.

Kırman, A., \& Doḡan, Ö. (2017). Anne-baba çocuk ilișkileri: bir meta-sentez çalıșması. Hacettepe Üniversitesi Saḡlık Bilimleri Fakültesi Dergisi, 4(1), 28-49.

Kunst, A. (2020). Changes to The General Lifestyle due to COVID-19 in Selected Countries 2020. Erișim Adresi: https://www.statista.com/statistics/1105960/changes-to-the-general-lifestyledue-tocovid-19-in-selected-countries/, [Erișim Tarihi: 24.08.2020].

COVID-19 "Evde Kal” Sürecinin Anne Görüşlerine Göre

Okul Öncesi Dönem Çocuklarının Günlük Yaşamlarına Yansıması 
Lau, E. Y. H., \& Lee, K. (2020). Parents' views on young children's distance learning and screen time during COVID-19 class suspension in Hong Kong. Early Education and Development, 1-18. DOI: 10.1080/10409289.2020.1843925.

Lecuelle, F., Leslie, W., Huguelet, S., Franco, P., \& Putois, B. (2020). Did the COVID-19 lockdown really have no impact on young children's sleep? J Clin Sleep Med, 16(12), 2121. https://doi. org/10.5664/jcsm.8806

Liu, Z., Tang, H., Jin, Q., Wang, G., Yang, Z., Chen, H., ... \& Owens, J. (2021). Sleep of preschoolers during the coronavirus disease 2019 (COVID-19) outbreak. Journal of Sleep Research, 3O(1), 1-7. https://doi.org/10.1111/jsr.13142

Mart, M., \& Kesicioḡlu, O. S. (2020). COVID-19 pandemi sürecinde ailelerin evde oyun oynamaya ilișkin görüșleri. Electronic Turkish Studies, 15(4), 945-958. . https://dx.doi.org/10.7827/ TurkishStudies.44381

Morelli, M., Cattelino, E., Baiocco, R., Trumello, C., Babore, A., Candelori, C., \& Chirumbolo, A. (2020). Parents and children during the COVID-19 lockdown: the Influence of parenting distress and parenting self-efficacy on children's emotional well-being. Front. Psychol. 11, 584-645. https:// doi.org/10.3389/fpsyg.2020.584645.

Pascal, C., \& Bertram, T. (2021). What do young children have to say? Recognising their voices, wisdom, agency and need for companionship during the COVID pandemic. European Early Childhood Education Research Journal, 29(1), 21-34. https://doi. org/10.1080/1350293X.2021.1872676

Pilan, B. S., Özbaran, B., Yüksel, G., Tortop, E., Calıșan, R., Yuluğ, B., ... \& Bildik, T. (2021). COVID-19 ve okul öncesi yaş grubu ruh sağ|ı̆̆ı. Ege Tıp Dergisi, 60(2), 128-135. https://doi.org/10.19161/ etd.951006

Prime, H., Wade, M., \& Browne, D. T. (2020). Risk and resilience in family well-being during the COVID-19 pandemic. American Psychologist. 75, 631-643. https://doi.org/10.1037/ amp0000660

Priyadharsini, H., \& Chiang, J. J. (2020). Embracing telehealth: supporting young children and families through occupational therapy in Singapore during COVID-19. World Federation of Occupational Therapists Bulletin, 76(2), 90-93. https://doi.org/10.1080/14473828.2020.1822574

Putri, R. S., Purwanto, A., Pramono, R., Asbari, M., Wijayanti, L. M., \& Hyun, C. C. (2020). Impact of the COVID-19 pandemic on online home learning: An explorative study of primary schools in Indonesia. International Journal of Advanced Science and Technology, 29(5), 4809-4818.

Saḡlam, M., \& Kay, M.A. (2020). COVID-19 Salgını Sürecinin Ailede Ebeveyn Tutumları İle Cocuklarda Duygusal ve Davranıșsal Durumlar Açısından Deḡerlendirilmesi. EJERCongress, 61.

Saurabh, K., \& Ranjan, S. (2020). Compliance and psychological impact of quarantine in children and adolescents due to Covid-19 pandemic. The Indian Journal of Pediatrics, 87, 532-536. https:// doi.org/10.1007/s12098-020-03347-3

Shorer, M., \& Leibovich, L. (2020). Young children's emotional stress reactions during the COVID-19 outbreak and their associations with parental emotion regulation and parental playfulness. Early Child Development and Care, 1-11. https://doi.org/10.1080/03004430.2020.1806830

Singh, S., Roy, D. K., Parveen, S., Sharma, G., \& Joshi. G. (2020). Impact of COVID-19 and lockdown on mental health of children and adolescents: A narrative review with recommendations. Psychiatry Research. 293, 1-10. https://doi.org/10.1016/j.psychres.2020.113429

52

Çocuk ve

Medeniyet 2021/1

Tarkoçin, S., Alagöz, N., \& Boḡa, E. (2020). Okul öncesi dönem çocuklarının pandemi sürecinde (COVID-19) davranıș deḡișiklikleri ve farkındalık düzeylerinin anne görüșlerine bașvurularak incelenmesi. Electronic Turkish Studies, 15(6), 1017-1036. https://dx.doi.org/10.7827/ TurkishStudies. 44338

\section{Ceren Arı Arat, Hülya Gülay Ogelman}


Toran, M., Sak, R., Xu, Y., Șahin-Sak, İ. T., \& Yu, Y. (2021). Parents and children during the COVID-19 quarantine process: Experiences from Turkey and China. Journal of Early Childhood Research. 1-19. https://doi.org/10.1177/1476718X20977583

Tran, T. , Hoang, A. D. , Nguyen, Y. C. , Nguyen, L. C. , Ta, N. T. , Pham, Q. H. , Pham C. X., Le Q. A., Dinh V. H., \& Nguyen T. T. (2020). Toward sustainable learning during school suspension: Socioeconomic, occupational aspirations, and learning behavior of Vietnamese students during CovID-19. Sustainability, 12(4195), 1-19. https://doi.org/10.3390/su12104195

Tural, E. (2020). COVID-19 pandemi dönemi ev karantinasında fiziksel aktivite düzeyinin yașam kalitesine etkisi . Van Sağlık Bilimleri Dergisi , 13(COVID-19 Özel Sayı) , 10-18.

Türkiye Cumhuriyeti İçișleri Bakanlığı. (2020). Şehir Giriș/Cıııș Tedbirleri ve Yaș Sınırlaması. https:// www.icisleri.gov.tr/sehir-giriscikis-tebirleri-ve-yas-sinirlamasi. [Erișim tarihi: 20 Şubat 2021]

Türkiye Cumhuriyeti Saḡlık Bakanlığı. (2020). COVID-19 (SARS-CoV-2 Enfeksiyonu) Rehberi. https:// covid19bilgi.saglik.gov.tr/depo/rehberler/COVID-19_Rehberi.pdf [ Erișim Tarihi: 02 Mayıs 2020].

United Nations Educational Scientific and Cultural Organization . (2020). COVID-19 impact on education . https://en.unesco.org/covid19/educationresponse [Erișim tarihi: 10 Mart 2021].

UNICEF, (2020a). COVID-19 and the impact on children's rights: the imperative for a human rightsbased approach [online]. UNICEF Programme Division, Human Rights Unit. Available from: https:// d3n8a8pro7vhmx.cloudfront.net/childrightsconnect/mailings/851/attachments/original/ UNICEF_COVID19_and_Child_Rights_Imperative_for_a_Human_Rights_Approach_Final_ April_2020.pdf?1588854658 [Erișim tarihi: 6 Mart 2021].

UNICEF, (2020b). COVID-19 Parenting. https://www.unicef.org/media/66146/file/COVID-19\%20 parenting\%20tips.pdf [Erișim tarihi: 6 Mart 2021].

Üstün, C.., \& Özçiftçi, S. (2020). COVID-19 pandemisinin sosyal yașam ve etik düzlem üzerine etkileri: Bir deḡerlendirme çalıșması. Anatolian Clinic the Journal of Medical Sciences, 25(Special Issue on COVID 19), 142-153.

World Federation of Occupational Therapy . (2020). Public statement. Occupational Therapy and rehabilitation of people affected by the COVID -19 pandemic.

World Health Organization. (2020a). Coronavirus disease (COVID-19) pandemic. Retrieved May 19, 2020 from https://www.who.int/ emergencies/diseases/novel-coronavirus2019?gclid=CjwKCAjw2 a32BRBXEiwAUcugiLkHUvUSXotOHRIKIM8uQmuDWm3TFhEODjA FCAo53S5jT-HaVAwfMRoCQeQQAvD_BwE

World Health Organization. (2020b). Q\&A on coronaviruses (COVID-19). https://www.who.int/ emergencies / diseases/novel-coronavirus-2019/question-and-answers-hub/q-a-detail/q-acoronaviruses [ Erișim Tarihi: 3 Mayıs 2020].

World Health Organization. (2021). WHO coronavirus (COVID-19) dashboard. https://covid19.who.int/ [Erișim Tarihi: 25 Aḡustos 2021].

Yıldııı, A., \& Șimșek, H. (2003). Sosyal bilimlerde nitel araștırma yöntemleri (3.Baskı). Ankara: Seçkin Yayıncılık. 


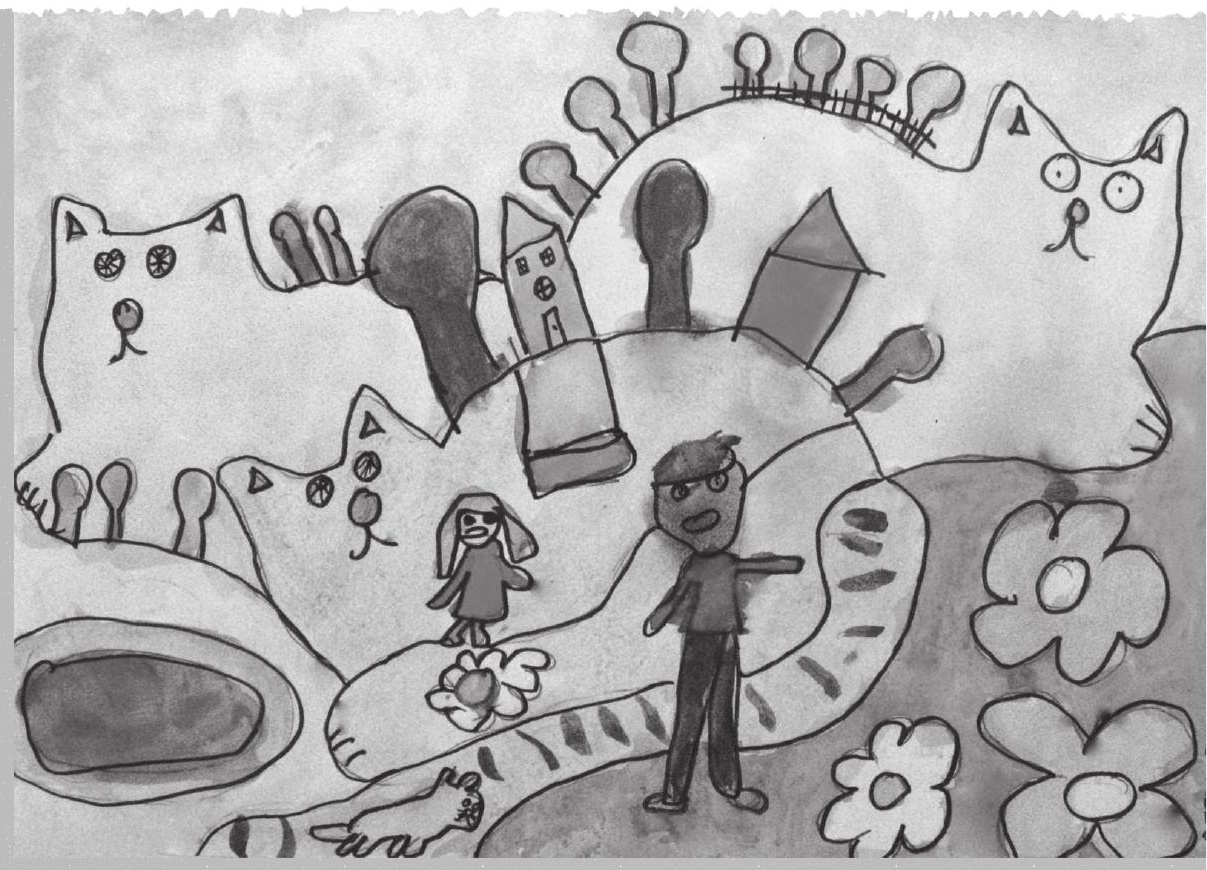

